\title{
Total Synthesis of (-)-Orthodiffenes A and C
}

\author{
Jun Liu, ${ }^{* \dagger, \dagger}$ Yi Liu, ${ }^{\dagger, \S}$ Xing Zhang, ${ }^{\dagger, \S}$ Chaoli Zhang, ${ }^{\dagger, \S}$ Yangguang Gao, ${ }^{\dagger, \S}$ LinLin Wang, ${ }^{\dagger, \S}$ \\ and Yuguo $\mathrm{Du}^{*, \dagger, \$}$
}

${ }^{\dagger}$ State Key Laboratory of Environmental Chemistry and Eco-toxicology, Research Center for Eco-Environmental Sciences, Chinese Academy of Sciences, Beijing 100085, China

${ }^{\ddagger}$ State Key Laboratory of Natural and Biomimetic Drugs, Peking University, Beijing, 100191, China

${ }^{\S}$ School of Chemistry and Chemical Engineering, Graduate University of Chinese Academy of Sciences, Beijing 100049, China

\section{Supporting Information}

ABSTRACT: The efficient and concise synthesis of (-)-orthodiffenes $\mathrm{A}$ and $\mathrm{C}$ has been accomplished for the first time in eight steps from readily available chiral synthons, D-mannose and D-ethyl lactate. Our work confirmed the complete structure of orthodiffenes $\mathrm{A}$ and $\mathrm{C}$, including their absolute stereochemistry. The key steps of our total synthesis involved cis-fused tetrahydrofuran cyclization, one-pot deprotectionlactonization, and intramolecular benzoyl migration according to a biosynthetic hypothesis of orthodiffenes.

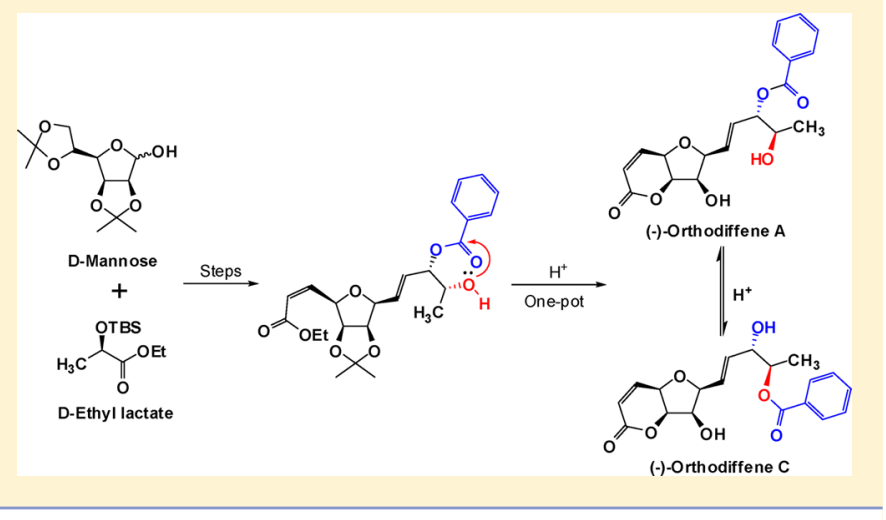

diffenes A-D are composed of a similar unusual furanopyrone skeleton with an extra olefinic side chain connecting at C8-C9. Furthermore, the four consecutive stereogenic centers (C5C8) on tetrahydrofuran framework were determined to be cis to each other from the coupling relationship. These all-syn tetrasubstituted furanopyrans are relatively rare in nature.

Despite the promising biological activity of orthodiffenes, the mode of action in terms of pharmacology remains unknown. To the best of our knowledge, the total synthesis of orthodiffenes has not been reported yet. The impressive biological activity, novel structural features, and the lack of structure-activity relationship (SAR) studies on orthodiffenes encouraged us to undertake a total synthesis of these novel natural products. Owing to the intriguing structural features of the unusual furanopyrone and consecutive all-syn tetrasubstituted tetrahydrofuran structural framework, the total synthesis of these compounds represents a challenge.

Orthodiffenes $\mathrm{A}$ and $\mathrm{C}$ have the same carbon backbone and stereochemistry, except for the benzoyl ester on the side chain which attaches to $\mathrm{C}-11$ and $\mathrm{C}-12$, respectively. This phenomenon is usually ascribed to the esterase involved in the natural biosynthetic process, suggesting that orthodiffenes $\mathrm{A}$ and $\mathrm{C}$ could be isomerized through an intramolecular ester migration at $\mathrm{C}-11$ and $\mathrm{C}-12$ via orthoester intermediates with retention of chirality. ${ }^{4}$ Accordingly, we expected that orthodiffenes $\mathrm{A}$ and $\mathrm{C}$ could be prepared from the same

Received: August 27, 2012

Published: October 11, 2012 
precursor and transformed to each other under a controlled benzoyl migration condition.

Due to the structural similarities between L-mannofuranoside and the desired furanopyrone skeleton (C3-C10) of orthodiffenes (Figure 1), we initially imagined that the natural orthodiffenes could be derived from unnatural L-mannose. Given the prohibitive cost of L-mannose and the unknown absolute configurations of the orthodiffenes, we were interested in synthesizing both the natural (1-4) and unnatural enantiomer $\left(\mathbf{1}^{\prime}-4^{\prime}\right)$ for structural determination and further biological studies. Consequently, our synthetic blueprint required swift access to either enantiomer of the orthodiffenes, based on the readily available natural carbohydrate D-mannose. Herein, we report the first total synthesis of (-)-orthodiffenes $\mathrm{A}$ and $\mathrm{C}$ by a short and efficient route.

\section{RESULTS AND DISCUSSION}

The retrosynthetic analysis of orthodiffenes $\mathrm{A}$ and $\mathrm{C}$ is outlined in Scheme 1. We envisaged that orthodiffenes $\mathrm{A}$ and $\mathrm{C}$ could be

Scheme 1. Retrosynthetic Analysis of Orthodiffenes A and C

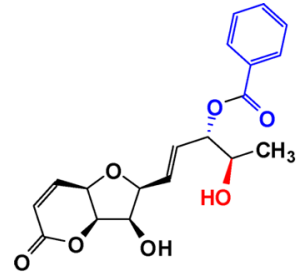

Orthodiffene A, (1')
Benzoyl Migration

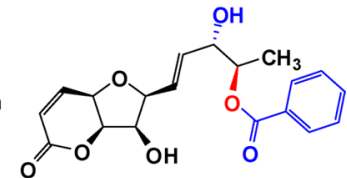

Orthodiffene C, (3') elaborated from well functionalized ( $Z$ )- $\alpha, \beta$-unsaturated ethyl ester 5 by one-pot acetonide deprotection/lactonization accompanied by benzoyl migration (Scheme 1). The transolefin moiety at $\mathrm{C} 9 / \mathrm{C} 10$ could be installed by coupling of $\beta$-D$C$-furanoside subunit 6 with the olefinic side chain 7 involving an olefin cross-metathesis strategy. The $\beta$-D- $C$-furanoside subunit 6 , in which all four cis stereocenters are in place, could be readily accessible from the natural carbohydrate 2,3:5,6-di-O-isopropylidene- $\alpha$-D-mannofuranose (8). The $\mathrm{Bz}$ and TBS group protected allylic alchol 7 can be easily prepared from D-ethyl lactate through reduction and Grignard addition by a one-pot sequence in three steps. Details of the studies thus undertaken are described below.

Our synthesis commenced with transformation of D-mannose to the diol 9 in two steps according to a modified procedure from Singh (Scheme 2). ${ }^{5}$ The known 2,3:5,6-di-O-isopropylidene- $\alpha$-D- mannofuranose (8), easily obtained from D-mannose in $90 \%$ yield using iodine as catalyst in dry acetone, ${ }^{6}$ was treated with 5.0 equiv of vinylmagnesium bromide, leading to a known compound 9 as a separable 5.3:1 mixture of diastereoisomers in almost quantitative yield (98\%). Attempts to improve the diastereoselectivity of this reaction by changing solvents or running at lower temperature $\left(-20{ }^{\circ} \mathrm{C}\right.$ to $\left.-80{ }^{\circ} \mathrm{C}\right)$ were fruitless. Chemoselective tosylation of diol 9, with 1.1 equiv of $p$-toluenesulfonyl chloride $(\mathrm{TsCl})$ in pyridine at 65 ${ }^{\circ} \mathrm{C}$, initiated a favorable regioselective intramolecular $\mathrm{S}_{\mathrm{N}} 2$ substitution at the allylic position to form the configurationinversed and cis-fused cyclization compound 6 in $84 \%$ yield. Other methods using triflic anhydride, ${ }^{8} \mathrm{FeCl}_{3},{ }^{9} \mathrm{SOCl}_{2},{ }^{10}$ and Mitsunobu reaction ${ }^{11}$ did not show an acceptable yield improvement. It is noteworthy that cis-fused tetrahydrofuran 6 was obtained as a single diastereomer, and the other isomers were not observed even when adding excessive $\mathrm{TsCl}$ (up to 2.2 equiv). The stereochemistry of the resulting $\beta$-C-glycosides was confirmed by NOE experiments and derivatization of $\mathbf{6}$ to the known compound $10^{12}$ in two steps (oxidative cleavage of olefins with osmium tetraoxide-sodium periodate ${ }^{13}$ followed by sodium borohydride reduction).

With the completion of the $\beta$-C-furanoside subunit, our attention was then focused on the synthesis of the olefinic side chain 7 as shown in Scheme 3. The protected allylic alchol 7 was prepared from D-ethyl lactate via the known TBS-protected ethyl lactate $11 .{ }^{14}$ Reduction of 11 with DIBAL-H to the corresponding lactaldehyde and subsequent treatment with vinylmagnesium chloride delivered the required $(R, S)-\mathbf{1 2}$ as a

Scheme 2. Synthesis of $\beta$-C-Glycosides 6
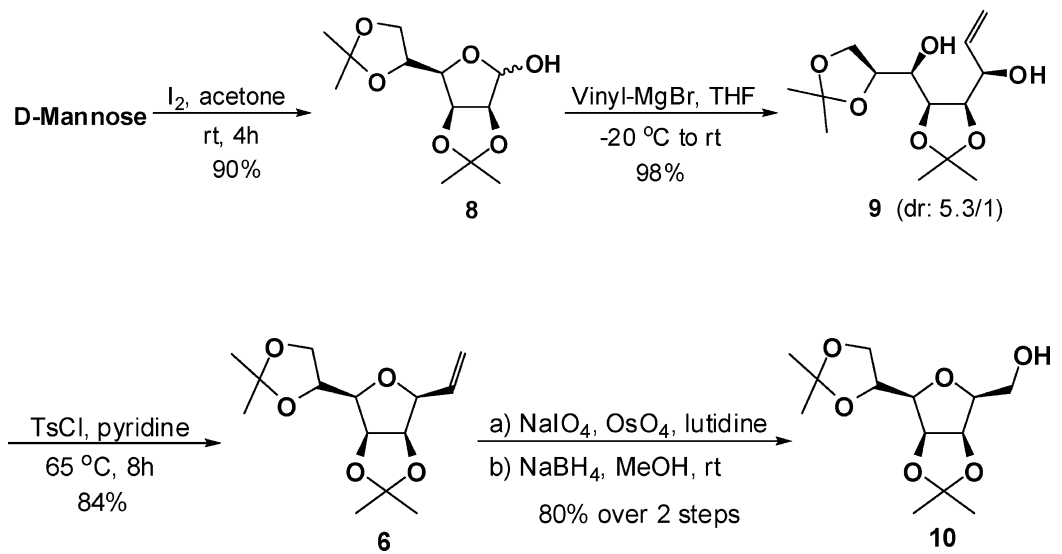
Scheme 3. Synthesis of 7

D-Ethyl lactate $\underset{\mathrm{DCM}, 99 \%}{\stackrel{\mathrm{TBSCl} \text {, imidazole }}{\longrightarrow}} \mathrm{C}_{3}$

7.8:1 mixture of diastereoisomers in a one-pot process. ${ }^{15}$ Blocking of the corresponding allylic alcohol as a benzoyl ester provided 7 . This approach afforded the desired protected allylic alchol 7 in a yield of $74 \%$ over three steps from D-ethyl lactate (Scheme 3).

With both key fragments in hand, we then investigate the olefin cross metathesis of $\beta$-C-furanoside 6 with 7 (Scheme 4). This reaction carried out smoothly using an excess of 7 (4.8 equiv) and a catalytic amount of Grubbs-II in DCM at room temperature for $12 \mathrm{~h}$ generated the desired olefin 13 in a yield of $67 \%$ with excellent E:Z selectivity $(>15: 1){ }^{16}$ Selective hydrolysis of the 1,2-acetonide and TBS protecting group with Amberlite IR-120 $\left(\mathrm{H}^{+}\right)$ion-exchange resin in methanol afforded 14 in $89 \%$ yield. Oxidative cleavage of the diol in $\mathbf{1 4}$ with $\mathrm{NaIO}_{4}$, followed by immediate Wittig olefination with (ethoxycarbonylmethylene)triphenylphosphorane, afforded predominantly $(Z)-\alpha, \beta$-unsaturated ester $\mathbf{5}$ in $80 \%$ yield with cis:trans > 13:1. ${ }^{17}$

After screening several conditions, we achieved one-pot acetonide deprotection/lactonization by treatment of $\mathbf{5}$ with a catalytic amount of $p$-toluenesulfonic acid (PTSA) in methanol, or $50 \%$ trifluoroacetic acid (TFA) aqueous solution in $\mathrm{THF}^{18}$ both approaches furnished a mixture of orthodiffenes A $\left(\mathbf{1}^{\prime}\right)$ and $C\left(3^{\prime}\right)$ which were readily separated by column chromatography (Scheme 4). Interestingly, treatment of either pure orthodiffene $A\left(\mathbf{1}^{\prime}\right)$ or orthodiffene $C\left(\mathbf{3}^{\prime}\right)$ with a catalytic amount of PTSA in methanol at room temperature for $72 \mathrm{~h}$ afforded a mixture of orthodiffenes $A\left(1^{\prime}\right)$ and $C\left(3^{\prime}\right)$ in a balanced ratio from $1: 1.3$ to $1: 1.7$ (Scheme 4$)$. We assumed that such an acidolysis equilibrium between orthodiffene A $\left(\mathbf{1}^{\prime}\right)$ and orthodiffene $C\left(3^{\prime}\right)$ probably resulted from a process of intramolecular transesterification via dioxolane intermediate. ${ }^{4 c}$ The spectroscopic data $\left({ }^{1} \mathrm{H},{ }^{13} \mathrm{C}\right.$ NMR, IR, and HRMS $)$ of both synthetic orthodiffene $A\left(\mathbf{1}^{\prime}\right)$ and orthodiffene $C\left(3^{\prime}\right)$ were in good agreement with those of the natural products (see the Supporting Information). However, the optical rotation obtained for synthetic samples are opposite in sign to the value reported for the natural products, which shows that our synthetic (-)-orthodiffene $A\left(\mathbf{1}^{\prime}\right)$ and $\mathrm{C}\left(\mathbf{3}^{\prime}\right)$ are the enantiomers of the natural products. ${ }^{19}$

\section{Scheme 4. Total Synthesis of Orthodiffenes A and C}
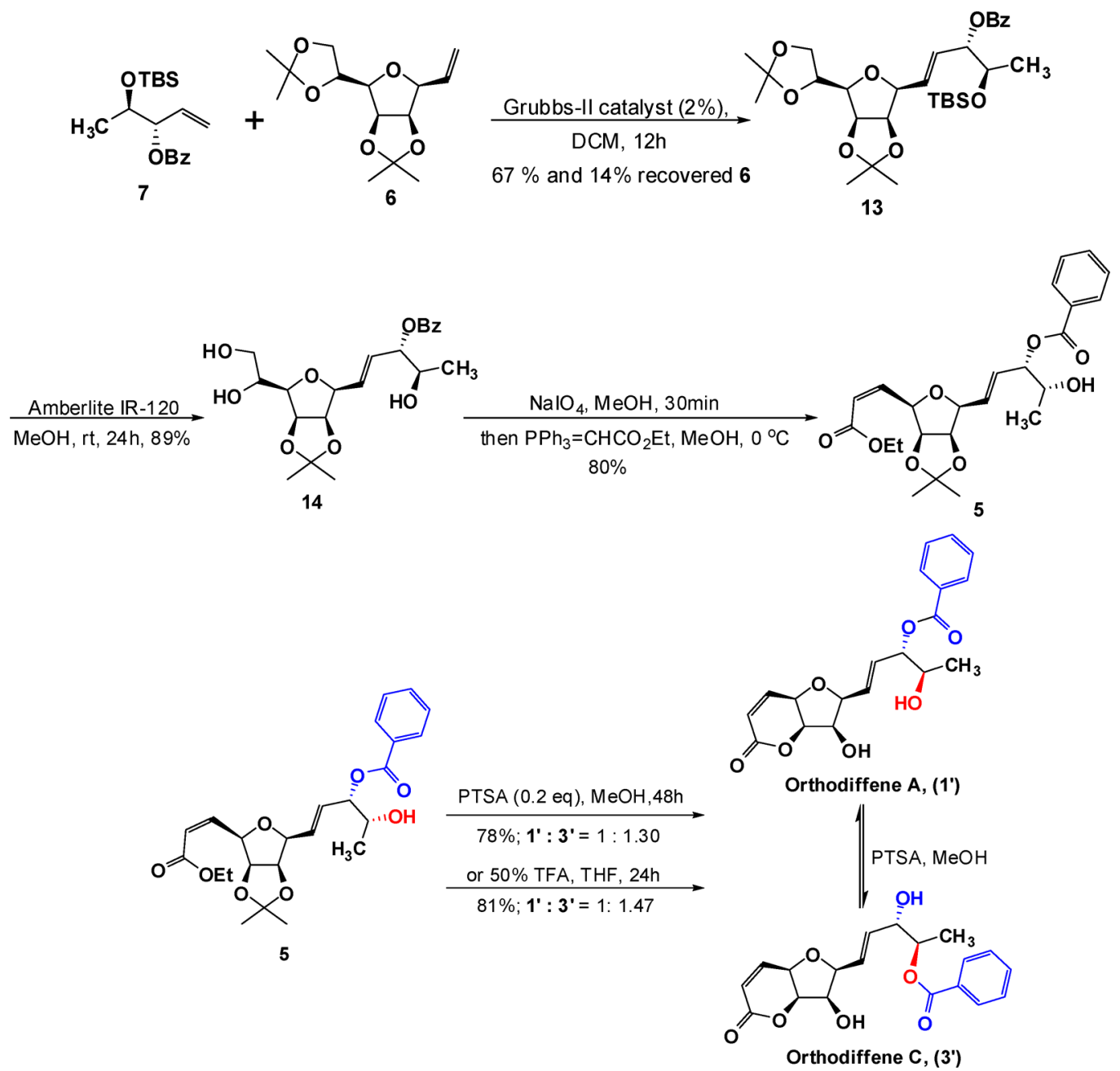


\section{CONCLUSION}

We have completed the first total synthesis of compounds $\mathbf{1}^{\prime}$ and $3^{\prime}$, the enantiomers of natural orthodiffenes $\mathrm{A}$ and $\mathrm{C}$, respectively, in eight steps from readily available D-mannose and D-ethyl lactate. The key transformations involved in this work are the tosylation-mediated, one-pot, cis-fused tetrahydrofuran cyclization, olefin cross metathesis, and one-pot tandem deprotection/lactonization. In addition, we observed intramolecular benzoyl migration between orthodiffene $C_{11}$ and $\mathrm{C}_{12}$ under acidic conditions in methanol, supporting a possible biotransformation of orthodiffenes through esterase-promoted ester migration. The current method offers an opportunity to prepare orthodiffenes $\mathrm{A}$ and $\mathrm{C}$ with the same process at the same time. We believe our strategy also provides a short and efficient approach for the syntheses of other orthodiffene-like natural products.

\section{EXPERIMENTAL SECTION}

1. General Experimental. Unless noted otherwise, commercially available materials were used without further purification. All solvents were dried according to the established procedures ahead of use. All reagents were purchased from commercial corporations. Flash chromatography (FC) was performed using silica gel (200-300 mesh) according to the standard protocol. All reactions under standard conditions were monitored by thin-layer chromatography (TLC) on gel F254 plates. Optical rotations were measured using a polarimeter with a thermally jacketed $5 \mathrm{~cm}$ cell at approximately $25{ }^{\circ} \mathrm{C}$. Infrared spectra were recorded as $\mathrm{KBr}$ discs using a FT-IR spectrophotometer with wave numbers expressed in $\mathrm{cm}^{-1}$. High-resolution mass spectrometry data (HRMS) were acquired using a Q-TOF analyzer in acetone as solvent. ${ }^{1} \mathrm{H}$ NMR and ${ }^{13} \mathrm{C}$ NMR were measured on 400 or $100 \mathrm{MHz}$ spectrometers (in $\mathrm{CDCl}_{3}$ with $\mathrm{TMS}$ as an internal standard). Chemical shifts $(\delta)$ are given in ppm relative to residual solvent (usually chloroform; $\delta 7.26$ for ${ }^{1} \mathrm{H}$ NMR or 77.0 for protondecoupled ${ }^{13} \mathrm{C}$ NMR), and coupling constants $(J)$ in hertz. Multiplicity is tabulated as $\mathrm{s}$ for singlet, $\mathrm{d}$ for doublet, $\mathrm{t}$ for triplet, $\mathrm{q}$ for quadruplet, $\mathrm{m}$ for multiplet, and br when the signal in question is broadened.

2. Experimental Procedures. Synthesis of $(3 a S, 4 R, 6 S, 6 a R)-4-$ ((R)-2,2-Dimethyl-1,3-dioxolan-4-yl)-2,2-dimethyl-6vinyltetrahydrofuro[3,4-d][1,3]dioxole (6). To a solution of 2,3:5,6di- $O$-isopropylidene- $\alpha$-D-mannofuranose $(6.9 \mathrm{~g}, 26.54 \mathrm{mmol})$ in dry THF $(60 \mathrm{~mL})$ was added vinylmagnesium bromide $(133 \mathrm{mmol})$ via syringe in three portions at $-20{ }^{\circ} \mathrm{C}$ under $\mathrm{N}_{2}$ protection. After $90 \mathrm{~min}$, the solution was warmed to room temperature and stirred for another $20 \mathrm{~h}$. The reaction was quenched by the slow addition of aq $\mathrm{NH}_{4} \mathrm{Cl}$ $(50 \mathrm{~mL}$, Caution!). The aqueous layer was extracted with ether $(3 \times$ $100 \mathrm{~mL}$ ). The combined organic phase was washed with brine, dried over $\mathrm{Na}_{2} \mathrm{SO}_{4}$, and concentrated under vacuum. The crude diol could be used for the next step without further purification. To a solution of crude diol (ca. $26.54 \mathrm{mmol})$ in dry pyridine $(60 \mathrm{~mL})$ was added $\mathrm{TsCl}$ $(11.2 \mathrm{~g}, 58.4 \mathrm{mmol})$ in three portions at $\mathrm{rt}$ under $\mathrm{N}_{2}$ protection. After $10 \mathrm{~min}$, the solution was warmed to $65^{\circ} \mathrm{C}$ and stirred for a further 8$10 \mathrm{~h}$. The reaction was quenched at $\mathrm{rt}$ by the addition of $\mathrm{MeOH}(20$ $\mathrm{mL})$. The solution was concentrated with toluene and poured into saturated aqueous $\mathrm{CuSO}_{4}(100 \mathrm{~mL})$ and then extracted with DCM (3 $\times 120 \mathrm{~mL}$ ). The combined organic phase was washed with brine, dried over $\mathrm{Na}_{2} \mathrm{SO}_{4}$, and concentrated under vacuum. The crude was purified by flash column chromatography (hexanes/EtOAc 7:1) to give compound 6 as a yellow oil (5.01 g, 70\% for two steps). $[\alpha]_{\mathrm{D}}^{25}$ $-16.1\left(\right.$ c 3.2, $\left.\mathrm{CHCl}_{3}\right) ;{ }^{1} \mathrm{H}$ NMR $(400 \mathrm{MHz}): \delta 1.31(\mathrm{~s}, 3 \mathrm{H}), 1.36(\mathrm{~s}$, $3 \mathrm{H}), 1.43(\mathrm{~s}, 3 \mathrm{H}), 1.47(\mathrm{~s}, 3 \mathrm{H}), 3.52(\mathrm{dd}, J=7.6 \mathrm{~Hz}, J=3.6 \mathrm{~Hz}, 1 \mathrm{H})$, $3.97(\mathrm{dd}, J=7.2 \mathrm{~Hz}, J=3.6 \mathrm{~Hz}, 1 \mathrm{H}), 4.04-4.11(\mathrm{~m}, 2 \mathrm{H}), 4.38-4.43$ $(\mathrm{m}, 1 \mathrm{H}), 4.65(\mathrm{dd}, J=6.0 \mathrm{~Hz}, J=3.6 \mathrm{~Hz}, 1 \mathrm{H}), 4.76(\mathrm{dd}, J=6.0 \mathrm{~Hz}, J$ $=3.6 \mathrm{~Hz}, 1 \mathrm{H}), 5.29(\mathrm{dd}, J=10.4 \mathrm{~Hz}, J=0.8 \mathrm{~Hz}, 1 \mathrm{H}), 5.35(\mathrm{dd}, J=$ $17.2 \mathrm{~Hz}, J=0.8 \mathrm{~Hz}, 1 \mathrm{H}), 5.95(\mathrm{ddd}, J=17.2 \mathrm{~Hz}, J=10.4 \mathrm{~Hz}, J=7.2$ $\mathrm{Hz}, 1 \mathrm{H}) ;{ }^{13} \mathrm{C}$ NMR $(100 \mathrm{MHz}) \delta 24.5,25.2,25.7,26.9,66.9,73.0$,
$80.8,81.6,82.5,83.2,108.9,112.5,119.2,132.1$; HRMS (ESI-TOF) $m / z:[\mathrm{M}+\mathrm{Na}]^{+}$Calcd for $\mathrm{C}_{14} \mathrm{H}_{22} \mathrm{O}_{5} \mathrm{Na}$ 293.1365; Found 293.1376.

Synthesis of ((3aR,4S,6R,6aS)-6-((R)-2,2-Dimethyl-1,3-dioxolan-4yl)-2,2-dimethyltetrahydrofuro[3,4-d][1,3]dioxol-4-yl)methanol (10). ${ }^{12}$ To a mixture of compound $6(108 \mathrm{mg}, 0.4 \mathrm{mmol}), 2,6$-lutidine $(0.1 \mathrm{~mL}, 0.79 \mathrm{mmol})$, and solid $\mathrm{NaIO}_{4}(129 \mathrm{mg}, 0.6 \mathrm{mmol})$ in dioxane $(8 \mathrm{~mL})$ and deionized $\mathrm{H}_{2} \mathrm{O}(2 \mathrm{~mL})$ was added a solution of $\mathrm{OsO}_{4}(5$ $\mathrm{mg})$ in ${ }^{\mathrm{t}} \mathrm{BuOH}$ and stirred at $\mathrm{rt}$ for $12 \mathrm{~h}$. After completion, the reaction was quenched by the addition of saturated aq $\mathrm{NH}_{4} \mathrm{Cl}(10 \mathrm{~mL})$. The reaction mixture was extracted with $\mathrm{DCM}(3 \times 10 \mathrm{~mL})$. The combined organic phase was washed with brine, dried over $\mathrm{Na}_{2} \mathrm{SO}_{4}$, and concentrated under vacuum. The crude aldehyde was used for the next step without further purification. To a solution of crude aldehyde (ca. $0.4 \mathrm{mmol})$ in $\mathrm{MeOH}(5 \mathrm{~mL})$ was added solid $\mathrm{NaBH}_{4}(31 \mathrm{mg}, 0.8$ $\mathrm{mmol}$ ) in two portions at $0{ }^{\circ} \mathrm{C}$. After $5 \mathrm{~min}$, the solution was warmed to $\mathrm{rt}$ and stirred for a further $15 \mathrm{~min}$. The mixture was concentrated under vacuum. The residue was added into saturated aqueous $\mathrm{NaCl}$ $(10 \mathrm{~mL})$ and extracted with DCM $(3 \times 50 \mathrm{~mL})$. The combined organic phase was dried over $\mathrm{Na}_{2} \mathrm{SO}_{4}$ and concentrated under vacuum. The crude material was purified by flash column chromatography (hexanes/EtOAc 1:1) to give compound $\mathbf{1 0}$ as a colorless oil $(88 \mathrm{mg}$, $80 \%$ for two steps). Data are consistent with a previously characterized compound. ${ }^{12}$

Synthesis of $(3 S, 4 R)-4$-(tert-Butyldimethylsilyloxy)pent-1-en-3-yl Benzoate (7). To a solution of TBS-protected lactate 11 (2.33 g, 10 $\mathrm{mmol})$ in dry ether $(50 \mathrm{~mL})$ was added DIBAL-H $(11.7 \mathrm{~mL}, 14$ mmol) via syringe in three portions at $-98{ }^{\circ} \mathrm{C}$ under $\mathrm{N}_{2}$ atmosphere. After $15 \mathrm{~min}$, vinylmagnesium chloride $(28.6 \mathrm{~mL}, 20 \mathrm{mmol})$ was added into the mixture via syringe. The solution was then warmed to room temperature and stirred overnight. The reaction was quenched by the slow addition of a saturated solution of $\mathrm{K} / \mathrm{Na}$ tartrate. $(80 \mathrm{~mL}$, Caution!). The aqueous layer was extracted with ether $(3 \times 80 \mathrm{~mL})$. The combined organic phase was washed with brine, dried over $\mathrm{Na}_{2} \mathrm{SO}_{4}$, and concentrated under vacuum. The crude allylic alcohol 12 was used for next step without further purification. To a solution of crude allylic alcohol (ca. $10 \mathrm{mmol})$ in dry pyridine $(25 \mathrm{~mL})$ was added $\mathrm{BzCl}(1.74 \mathrm{~mL}, 15 \mathrm{mmol})$ by two portions at $0{ }^{\circ} \mathrm{C}$. After $15 \mathrm{~min}$, the solution was warmed to $\mathrm{rt}$ and stirred for a further $15 \mathrm{~min}$. The reaction was quenched by the addition of $\mathrm{MeOH}(10 \mathrm{~mL})$ and concentrated with toluene. The residue was poured into saturated aqueous $\mathrm{CuSO}_{4}(50 \mathrm{~mL})$ and extracted with DCM $(3 \times 50 \mathrm{~mL})$. The combined organic phase was washed with brine, dried over $\mathrm{Na}_{2} \mathrm{SO}_{4}$, and concentrated under vacuum. The crude was purified by flash column chromatography (hexanes/EtOAc 30:1) to give compound 7 as a colorless oil $\left(2.36 \mathrm{~g}, 74 \%\right.$ for two steps). $[\alpha]_{\mathrm{D}}{ }^{25}-24.8(c$ 1.7, $\left.\mathrm{CHCl}_{3}\right) ;{ }^{1} \mathrm{H}$ NMR $(400 \mathrm{MHz}): \delta 0.04(\mathrm{~s}, 6 \mathrm{H}), 0.89(\mathrm{~s}, 9 \mathrm{H}), 1.20(\mathrm{~d}, J$ $=6.4 \mathrm{~Hz}, 3 \mathrm{H}), 4.02-4.09(\mathrm{~m}, 1 \mathrm{H}), 5.26-5.45(\mathrm{~m}, 3 \mathrm{H}), 5.96-6.05$ (ddd, $J=17.2 \mathrm{~Hz}, J=10.4 \mathrm{~Hz}, J=6.8 \mathrm{~Hz}, 1 \mathrm{H}) ; 7.44(\mathrm{t}, J=7.6 \mathrm{~Hz}$, $2 \mathrm{H}), 7.56(\mathrm{t}, J=7.6 \mathrm{~Hz}, 1 \mathrm{H}), 8.07(\mathrm{~d}, J=7.6 \mathrm{~Hz}, 2 \mathrm{H}) ;{ }^{13} \mathrm{C} \mathrm{NMR}(100$ $\mathrm{MHz}) \delta-4.8,-4.5,18.0,19.8,25.7,69.7,79.4,118.7,128.3,129.7$, 130.6, 132.9, 133.1, 165.7; HRMS (ESI-TOF) $m / z:[\mathrm{M}+\mathrm{Na}]^{+}$Calcd for $\mathrm{C}_{18} \mathrm{H}_{28} \mathrm{O}_{3} \mathrm{SiNa}$ 343.1705; Found 343.1708.

Synthesis of $(3 S, 4 R, E)-4-(t e r t-B u t y l d i m e t h y l s i l y l o x y)-1-((3 a R, 4 S, 6-$ $R, 6 a S)$ - 6-((R)-2,2-dimethyl-1,3-dioxolan-4-yl)-2,2dimethyltetrahydrofuro[3, 4-d][1,3]dioxol-4-yl)pent-1-en-3-yl Benzoate (13). Grubbs second catalyst (15 $\mathrm{mg}, 0.018 \mathrm{mmol})$ was added to a mixture of $7(1.38 \mathrm{~g}, 4.3 \mathrm{mmol})$ and $6(243 \mathrm{mg}, 0.9 \mathrm{mmol})$ in dry DCM $(75 \mathrm{~mL})$. The reaction was stirred for $12 \mathrm{~h}$ at rt. The solution was concentrated and purified by flash column chromatography (hexanes/EtOAc 6:1) to give compound 13 as a colorless oil $(339 \mathrm{mg}$, $67 \%)$ and $6(34 \mathrm{mg}, 14 \%)$. $[\alpha]_{\mathrm{D}}{ }^{25} 13.8\left(\right.$ c $\left.2.1, \mathrm{CHCl}_{3}\right) ;{ }^{1} \mathrm{H}$ NMR $(400$ $\mathrm{MHz}): \delta 0.02(\mathrm{~s}, 3 \mathrm{H}), 0.03(\mathrm{~s}, 3 \mathrm{H}), 0.88(\mathrm{~s}, 9 \mathrm{H}), 1.19(\mathrm{~d}, J=6.0 \mathrm{~Hz}$, $3 \mathrm{H}), 1.29(\mathrm{~s}, 3 \mathrm{H}), 1.37(\mathrm{~s}, 3 \mathrm{H}), 1.39(\mathrm{~s}, 3 \mathrm{H}), 1.44(\mathrm{~s}, 3 \mathrm{H}), 3.52$ (dd, $J$ $=7.6 \mathrm{~Hz}, J=3.6 \mathrm{~Hz}, 1 \mathrm{H}), 4.01(\mathrm{dd}, J=6.4 \mathrm{~Hz}, J=3.6 \mathrm{~Hz}, 1 \mathrm{H}), 4.03-$ $4.10(\mathrm{~m}, 3 \mathrm{H}), 4.38-4.42(\mathrm{~m}, 1 \mathrm{H}), 4.65(\mathrm{dd}, J=6.0 \mathrm{~Hz}, J=3.6 \mathrm{~Hz}$, $1 \mathrm{H}), 4.76(\mathrm{dd}, J=6.0 \mathrm{~Hz}, J=3.6 \mathrm{~Hz}, 1 \mathrm{H}), 5.41(\mathrm{dd}, J=6.4 \mathrm{~Hz}, J=4.0$ $\mathrm{Hz}, 1 \mathrm{H}), 5.90(\mathrm{dd}, J=16.0 \mathrm{~Hz}, J=6.4 \mathrm{~Hz}, 1 \mathrm{H}), 5.97(\mathrm{dd}, J=16.0 \mathrm{~Hz}$, $J=6.4 \mathrm{~Hz}, 1 \mathrm{H}), 7.41-7.45(\mathrm{~m}, 2 \mathrm{H}), 7.54(\mathrm{dt}, J=7.6 \mathrm{~Hz}, J=1.2 \mathrm{~Hz}$, $1 \mathrm{H}), 8.05-8.07(\mathrm{~m}, 2 \mathrm{H}) ;{ }^{13} \mathrm{C}$ NMR $(100 \mathrm{MHz}) \delta-4.8,-4.5,18.0$, $19.9,24.7,25.3,25.7,25.8,26.9,67.0,69.7,73.1,78.4,80.9,81.7,82.2$, 
$82.5,109.0,112.6,128.2,128.5,129.3,129.7,130.6,132.8,165.6$; HRMS (ESI-TOF) $m / z:[\mathrm{M}+\mathrm{Na}]^{+}$Calcd for $\mathrm{C}_{30} \mathrm{H}_{46} \mathrm{O}_{8} \mathrm{SiNa}$ 585.2860; Found 585.2863.

Synthesis of $(3 S, 4 R, E)-1-((3 a R, 4 S, 6 R, 6 a S)-6-((Z)-3-E t h o x y-3-o x o-$ prop-1-enyl)-2, 2-dimethyltetrahydrofuro[3,4-d][1,3]dioxol-4-yl)-4hydroxypent-1-en-3-yl Benzoate (5). Amberlite IR-120 acidic resin $(25 \mathrm{mg})$ was added to the solution of $13(175 \mathrm{mg}, 0.31 \mathrm{mmol})$ in $\mathrm{MeOH}(15 \mathrm{~mL})$. The reaction was stirred for $24 \mathrm{~h}$ at $\mathrm{rt}$. The solid resin was filtered with cotton wool. The solution was concentrated under vacuum to afford 14 as a colorless oil. The crude triol 14 could be used for the next step without any purification. A small sample was purified on a silica gel column to get the physical data of 14: $[\alpha]_{\mathrm{D}}{ }^{25}$ $31.0\left(c 1.0, \mathrm{CHCl}_{3}\right) ;{ }^{1} \mathrm{H}$ NMR $(400 \mathrm{MHz}): \delta 1.25(\mathrm{~d}, J=6.4 \mathrm{~Hz}, 3 \mathrm{H})$, $1.30(\mathrm{~s}, 3 \mathrm{H}), 1.40(\mathrm{~s}, 3 \mathrm{H}), 2.56(\mathrm{br} \mathrm{s}, 3 \mathrm{H}), 3.56(\mathrm{dd}, J=8.0 \mathrm{~Hz}, J=3.6$ $\mathrm{Hz}, 1 \mathrm{H}), 3.74(\mathrm{dd}, J=11.6 \mathrm{~Hz}, J=5.6 \mathrm{~Hz}, 1 \mathrm{H}), 3.85(\mathrm{dd}, J=11.6 \mathrm{~Hz}$, $J=3.2 \mathrm{~Hz}, 1 \mathrm{H}), 4.00-4.09(\mathrm{~m}, 3 \mathrm{H}), 4.66(\mathrm{dd}, J=6.0 \mathrm{~Hz}, J=3.6 \mathrm{~Hz}$, $1 \mathrm{H}), 4.83(\mathrm{dd}, J=6.0 \mathrm{~Hz}, J=4.0 \mathrm{~Hz}, 1 \mathrm{H}), 5.48(\mathrm{dd}, J=4.8 \mathrm{~Hz}, J=0.4$ $\mathrm{Hz}, 1 \mathrm{H}), 5.92(\mathrm{dd}, J=16.0 \mathrm{~Hz}, J=5.6 \mathrm{~Hz}, 1 \mathrm{H}), 6.00(\mathrm{dd}, J=16.0 \mathrm{~Hz}$, $J=5.6 \mathrm{~Hz}, 1 \mathrm{H}), 7.42-7.46(\mathrm{~m}, 2 \mathrm{H}), 7.58(\mathrm{dt}, J=7.2 \mathrm{~Hz}, J=1.2 \mathrm{~Hz}$, $1 \mathrm{H}), 8.05-8.07(\mathrm{~m}, 2 \mathrm{H}) ;{ }^{13} \mathrm{C}$ NMR $(100 \mathrm{MHz}) \delta 18.5,24.8,25.8$, 64.5, 69.0, 70.1, 77.9, 80.9, 81.3, 81.6, 82.2, 112.8, 127.8, 128.4, 129.1, 129.7, 130.1, 133.1, 165.7; HRMS (ESI-TOF) $m / z:[\mathrm{M}+\mathrm{Na}]^{+}$Calcd for $\mathrm{C}_{21} \mathrm{H}_{28} \mathrm{O}_{8} \mathrm{Na}$ 431.1682; Found 431.1671. To a solution of triol 14 $(102 \mathrm{mg}, 0.25 \mathrm{mmol})$ in $\mathrm{MeOH}(20 \mathrm{~mL})$ was added solid $\mathrm{NaIO}_{4}(80$ $\mathrm{mg}, 0.375 \mathrm{mmol}$ ) at rt. The mixture was stirred for $30 \mathrm{~min}$ and filtered with Celite. To the resulting solution was added (ethoxycarbonylmethylene)triphenylphosphorane (174 mg, 0.5 mmol) at $0{ }^{\circ} \mathrm{C}$. After being stirred at $0{ }^{\circ} \mathrm{C}$ for $60 \mathrm{~min}$, the reaction was concentrated under vacuum. The crude material was purified by flash column chromatography (hexanes/EtOAc 2:1) to give compound 5 as a colorless oil $(89 \mathrm{mg}, 80 \%) .[\alpha]_{\mathrm{D}}{ }^{25}-41.4(c 3.5$, $\left.\mathrm{CHCl}_{3}\right) ;{ }^{1} \mathrm{H}$ NMR $(400 \mathrm{MHz}): \delta 1.25(\mathrm{~s}, 3 \mathrm{H}), 1.26(\mathrm{t}, \mathrm{J}=6.8 \mathrm{~Hz}$, $3 \mathrm{H}), 1.27(\mathrm{~d}, J=6.0 \mathrm{~Hz}, 3 \mathrm{H}), 1.40(\mathrm{~s}, 3 \mathrm{H}), 2.42(\mathrm{br} \mathrm{s}, 1 \mathrm{H}), 4.00-4.08$ $(\mathrm{m}, 1 \mathrm{H}), 4.10(\mathrm{dd}, J=5.6 \mathrm{~Hz}, J=4.0 \mathrm{~Hz}, 1 \mathrm{H}), 4.16(\mathrm{q}, J=6.8 \mathrm{~Hz}$, $2 \mathrm{H}), 4.68(\mathrm{dd}, J=5.6 \mathrm{~Hz}, J=4.0 \mathrm{~Hz}, 1 \mathrm{H}), 5.03(\mathrm{dd}, J=6.0 \mathrm{~Hz}, J=3.6$ $\mathrm{Hz}, 1 \mathrm{H}), 5.05-5.08(\mathrm{~m}, 1 \mathrm{H}), 5.51(\mathrm{dd}, J=6.0 \mathrm{~Hz}, J=4.0 \mathrm{~Hz}, 1 \mathrm{H})$, $5.94-6.01(\mathrm{~m}, 2 \mathrm{H}), 6.05(\mathrm{dd}, J=16.0 \mathrm{~Hz}, J=5.6 \mathrm{~Hz}, 1 \mathrm{H}), 6.35(\mathrm{dd}, J$ $=12.0 \mathrm{~Hz}, J=6.4 \mathrm{~Hz}, 1 \mathrm{H}), 7.43(\mathrm{t}, J=8.0 \mathrm{~Hz}, 2 \mathrm{H}), 7.54-7.58(\mathrm{~m}$, $1 \mathrm{H}), 8.05-8.07(\mathrm{~m}, 2 \mathrm{H})$; ${ }^{13} \mathrm{C}$ NMR $(100 \mathrm{MHz}) \delta 14.1,18.5,24.8$, 25.8, 60.4, 69.0, 78.0, 78.6, 81.5, 82.4, 82.9, 112.5, 120.9, 127.8, 128.3, 129.4, 129.7, 130.1, 133.1, 144.8, 165.7; HRMS (ESI-TOF) $\mathrm{m} / z$ : [M + $\mathrm{Na}]^{+}$Calcd for $\mathrm{C}_{24} \mathrm{H}_{30} \mathrm{O}_{8} \mathrm{Na}$ 469.1838; Found 469.1810.

Synthesis of Orthodiffene $A\left(1^{\prime}\right)$ and Orthodiffene $C\left(3^{\prime}\right)$. To a solution of ester $5(42 \mathrm{mg}, 0.094 \mathrm{mmol})$ in $\mathrm{MeOH}(5 \mathrm{~mL})$ was added PTSA $\cdot \mathrm{H}_{2} \mathrm{O}(3.6 \mathrm{mg}, 0.019 \mathrm{mmol})$ at $\mathrm{rt}$. The mixture was stirred for 48 and concentrated under vacuum. The crude was purified by flash column chromatography (hexanes/EtOAc 1:3) to give orthodiffene A $\left(\mathbf{1}^{\prime}\right)(11.5 \mathrm{mg}, 34 \%)$ and orthodiffene $\mathrm{C}\left(3^{\prime}\right)(14.9 \mathrm{mg}, 44 \%)$. Orthodiffene A $\left(\mathbf{1}^{\prime}\right)$ : white solid, $[\alpha]_{\mathrm{D}}{ }^{25}-35.2\left(\mathrm{c} 0.8, \mathrm{CHCl}_{3}\right) ;{ }^{1} \mathrm{H}$ NMR $(400 \mathrm{MHz}): \delta 1.25(\mathrm{~d}, J=6.8 \mathrm{~Hz}, 3 \mathrm{H}), 3.05(\mathrm{br} \mathrm{s}, 2 \mathrm{H}), 4.04$ $(\mathrm{dq}, J=6.8 \mathrm{~Hz}, J=2.0 \mathrm{~Hz}, 1 \mathrm{H}), 4.47(\mathrm{t}, J=4.8 \mathrm{~Hz}, 1 \mathrm{H}), 4.55(\mathrm{dd}, J=$ $4.8 \mathrm{~Hz}, J=4.0 \mathrm{~Hz}, 1 \mathrm{H}), 4.61(\mathrm{ddd}, J=6.8 \mathrm{~Hz}, J=4.0 \mathrm{~Hz}, J=1.2 \mathrm{~Hz}$, $1 \mathrm{H}), 5.06(\mathrm{dd}, J=6.8 \mathrm{~Hz}, J=4.8 \mathrm{~Hz}, 1 \mathrm{H}), 5.39-5.42(\mathrm{~m}, 1 \mathrm{H}), 5.90$ $(\mathrm{dd}, J=15.6 \mathrm{~Hz}, J=4.4 \mathrm{~Hz}, 1 \mathrm{H}), 5.93(\mathrm{dd}, J=15.6 \mathrm{~Hz}, J=4.4 \mathrm{~Hz}$, $1 \mathrm{H}), 6.08(\mathrm{dd}, J=10.0 \mathrm{~Hz}, J=1.2 \mathrm{~Hz}, 1 \mathrm{H}), 6.79(\mathrm{dd}, J=10.0 \mathrm{~Hz}, J=$ $4.0 \mathrm{~Hz}, 1 \mathrm{H}), 7.45(\mathrm{t}, J=8.0 \mathrm{~Hz}, 2 \mathrm{H}), 7.56-7.59(\mathrm{~m}, 1 \mathrm{H}), 8.04-8.06$ $(\mathrm{m}, 2 \mathrm{H}) ;{ }^{13} \mathrm{C}$ NMR $(100 \mathrm{MHz}) \delta 18.7,67.1,69.0,73.6,78.1,79.1$, $79.3,121.9,128.4,128.6,129.5,129.7,130.0,133.3,141.6,161.1$, 165.8; IR (film): 3410, 2923, 2852, 1713, 1633, 1452, 1261, 1106, 1025, $802 \mathrm{~cm}^{-1}$; HRMS (ESI-TOF) $\mathrm{m} / z:[\mathrm{M}+\mathrm{Na}]^{+}$Calcd for $\mathrm{C}_{19} \mathrm{H}_{20} \mathrm{O}_{7} \mathrm{Na}$ 383.1107; Found 383.1093. Orthodiffene C $\left(\mathbf{3}^{\prime}\right)$ : white solid, $[\alpha]_{\mathrm{D}}{ }^{25}-33.7\left(c 0.6, \mathrm{CHCl}_{3}\right) ;{ }^{1} \mathrm{H}$ NMR $(400 \mathrm{MHz}): \delta 1.36$ (d, $J$ $=6.8 \mathrm{~Hz}, 3 \mathrm{H}), 2.48(\mathrm{br} \mathrm{s}, 2 \mathrm{H}), 4.36(\mathrm{t}, J=4.4 \mathrm{~Hz}, 1 \mathrm{H}), 4.38-4.41(\mathrm{~m}$, $1 \mathrm{H}), 4.48(\mathrm{dd}, J=4.8 \mathrm{~Hz}, J=4.0 \mathrm{~Hz}, 1 \mathrm{H}), 4.60(\mathrm{ddd}, J=6.0 \mathrm{~Hz}, J=$ $4.0 \mathrm{~Hz}, J=0.8 \mathrm{~Hz}, 1 \mathrm{H}), 5.04(\mathrm{dd}, J=6.0 \mathrm{~Hz}, J=4.8 \mathrm{~Hz}, 1 \mathrm{H}), 5.18$ $(\mathrm{dq}, J=6.8 \mathrm{~Hz}, J=4.4 \mathrm{~Hz}, 1 \mathrm{H}), 5.87(\mathrm{dd}, J=15.6 \mathrm{~Hz}, J=4.8 \mathrm{~Hz}$, $1 \mathrm{H}), 5.92(\mathrm{dd}, J=15.6 \mathrm{~Hz}, J=4.8 \mathrm{~Hz}, 1 \mathrm{H}), 6.06(\mathrm{dd}, J=10.0 \mathrm{~Hz}, J=$ $0.8 \mathrm{~Hz}, 1 \mathrm{H}), 6.74(\mathrm{dd}, J=10.0 \mathrm{~Hz}, J=4.0 \mathrm{~Hz}, 1 \mathrm{H}), 7.43(\mathrm{t}, J=8.0 \mathrm{~Hz}$, $2 \mathrm{H}), 7.53-7.58(\mathrm{~m}, 1 \mathrm{H}), 8.02-8.04(\mathrm{~m}, 2 \mathrm{H}) ;{ }^{13} \mathrm{C} \mathrm{NMR}(100 \mathrm{MHz}) \delta$ $15.1,66.9,73.5,73.6,74.1,79.0,79.4,121.6,127.5,128.4,129.6,130.2$,
132.8, 133.1, 141.9, 161.3, 166.2; IR (film): 3418, 2925, 2853, 1713, 1632, 1451, 1262, 1110, $802 \mathrm{~cm}^{-1}$; HRMS (ESI-TOF) $\mathrm{m} / z:[\mathrm{M}+$ $\mathrm{Na}]^{+}$Calcd for $\mathrm{C}_{19} \mathrm{H}_{20} \mathrm{O}_{7} \mathrm{Na}$ 383.1107; Found 383.1089;

\section{ASSOCIATED CONTENT}

\section{Supporting Information}

Spectral data for all new compounds. This material is available free of charge via the Internet at http://pubs.acs.org.

\section{AUTHOR INFORMATION}

\section{Corresponding Author}

*E-mail: junliu@rcees.ac.cn; duyuguo@rcees.ac.cn.

Notes

The authors declare no competing financial interest.

\section{ACKNOWLEDGMENTS}

This work was supported by the MOST of China (2012ZX09502001-001), NNSF of China (projects 2012CB822101, 21072217, and 21202193). We gratefully acknowledge financial support from the State Key Laboratory of Natural and Biomimetic Drugs of Peking University (K20110101). We also thank Professor Chu-Yi Yu of CAS Key Laboratory of Molecular Recognition and Function (Institute of Chemistry, Chinese Academy of Sciences) for kindly measuring the optical rotation of orthodiffene $\mathrm{A}\left(\mathbf{1}^{\prime}\right)$ and orthodiffene $\mathrm{C}\left(3^{\prime}\right)$.

\section{REFERENCES}

(1) (a) Danishefsky, S. Nat. Prod. Rep. 2010, 27, 1114-1116. (b) Newman, D. J.; Cragg, G. M. J. Nat. Prod. 2012, 75, 311-335.

(2) Tan, G.; Gyllenhaal, C.; Soejarto, D. D. Curr. Drug Targets 2006, 7, 265-277.

(3) Harish, H.; Srinivas, Y.; Majhi, A.; Srinivasulu, G.; Sridhar, B.; Krishna, A. S.; Rao, J. V.; Das, B. Tetrahedron Lett . 2011, 52, 49-52.

(4) For examples of the transformation of natural products based on the intramolecular transesterification reaction, see: (a) Thuggacins A-C: Steinmetz, H.; Irschik, H.; Kunze, B.; Reichenbach, H.; Hofle, G.; Jansen, R. Chem.-Eur. J. 2007, 13, 5822-5832. (b) Chondropsins A and D: Rashid, M. A.; Cantrell, C. L.; Gustafson, K. R.; Boyd, M. R. J. Nat. Prod. 2001, 64, 1341-1344. (c) Salvinorins D and E: Kutrzeba, L. M.; Li, X. C.; Ding, Y.; Ferreira, D.; Zjawiony, J. K. J. Nat. Prod. 2010, 73, 707-708.

(5) van Boggelen, M. P.; van Dommelen, B. F. G. A.; Jiang, S.; Singh, G. Tetrahedron 1997, 53, 16897-16910.

(6) Schmidt, O. T. Methods in Carbohydrate Chemistry; Whistler, R. L., Wolfrom, M. L., Eds.; Academic Press Inc.: New York, 1963; Vol. 2, pp 318-319.

(7) Buchanan, J. G.; Dunn, A. D.; Edgar, A. R. J. Chem. Soc., Perkin Trans. 1 1975, 1191-1200.

(8) Martin, O. R.; Yang, F.; Xie, F. Tetrahedron Lett. 1995, 36, 47-50.

(9) Sharma, G. V. M; Kumar, K. R.; Sreenivas, P.; Krishna, P. R.; Chorgade, M. S. Tetrahedron: Asymmetry 2002, 13, 687-690.

(10) Cordero-Vargas, A.; Quiclet-Sire, B.; Zard, S. Z. Org. Biomol. Chem. 2005, 3, 4432-4443.

(11) (a) Mitsunobu, O. Synthesis 1981, 1-28. (b) Yokayama, M.; Toyoshima, H.; Shimizu, M.; Togo, H. J. Chem. Soc., Perkin Trans. 1 1997, 29.

(12) (a) Frechou, C.; Dheilly, L.; Beaupere, D.; Uzanet, R.; Demailly, D. Tetrahedron Lett. 1992, 33, 5067-5070. (b) Mereyala, H. B.; Gadikota, R. R.; Maju, J.; Arora, S. K.; Dastida, S. G.; Agarwal, S. Bioorg. Med. Chem. 1999, 7, 2095-2103.

(13) Yu, W. S.; Mei, Y.; Kang, Y.; Hua, Z. M.; Jin, Z. D. Org. Lett. 2004, 6, 3217-3219.

(14) Massad, S. K.; Hawkins, L. D.; Baker, D. C. J. Org. Chem. 1983, $48,5180-5182$.

(15) Schmidt, B.; Biernat, A. Chem.-Eur. J. 2008, 14, 6135-6141. 
(16) (a) Scholl, M.; Ding, S.; Lee, C. W.; Grubbs, R. H. Org. Lett. 1999, 1, 953-956. (b) Chatterjee, A . K.; Choi, T. L.; Sanders, D. P.; Grubbs, R. H. J. Am. Chem. Soc. 2003, 125, 11360-11370.

(17) The Wittig reaction of stabilized ylides with $\alpha$-alkoxy or $\beta$-alkoxy aldehydes can stereoselectively form (Z)- $\alpha, \beta$-unsaturated ester in alcoholic solvents, and the correlation between the structure of the starting carbonyl compound and the stereoselectivity of the reaction was also well established; For preliminary communications, see: (a) Tronchet, J. M. J.; Gentile, B. Helv. Chim. Acta 1979, 62, 20912098. (b) Minari, N.; Ko, S. S.; Kishi, Y. J. Am. Chem. Soc. 1982, 104, 1109-1111. (c) Valverde, S.; Martin-Lomas, M.; Herradon, B.; GarciaOchoa, S. Tetrahedron 1987, 43, 1895-1901. (d) Sanchez-Sancho, F.; Valverde, S.; Herradon, B. Tetrahedron: Asymmetry 1996, 7, 32093246. For a comprehensive review, see: (e) Maryanoff, B. E.; Reitz, A. B. Chem. Rev. 1989, 89, 863-927. For a recent synthesis of natural products involving the reactions, see: (f) Baird, L. J.; Timmer, M. S. M.; Teesdale-Spittle, P. H.; Harvey, J. E. J. Org. Chem. 2009, 74, 22712277. (g) Barros, M. T.; Charmier, M. A. J.; Maycock, C. D.; Michaud, T. Tetrahedron 2009, 65, 396-399. (h) Du, Y. G.; Liu, J.; Linhardt, R. J. J. Org. Chem. 2007, 72, 3952-3954. (i) Sabitha, G.; Swapna, R.; Babu, R. S.; Yadav, J. S. Tetrahedron Lett. 2005, 46, 6145-6148. (j) Lee, H. K.; Chun, J. S.; Pak, C. S. J. Org. Chem. 2003, 68, 24712474.

(18) (a) Meira, P. R. R.; Moro, A. V.; Correia, C. R. D. Synthesis 2007, 2279-2286. (b) Dowex 50WX8 and $\mathrm{HCl} / \mathrm{MeOH}$ were also employed for the one-pot acidolysis. However, the desired product was obtained in a low yield $(5-10 \%)$.

(19) Synthetic orthodiffene A and orthodiffene C exhibit physical properties $\left({ }^{1} \mathrm{H},{ }^{13} \mathrm{C} \mathrm{NMR}\right.$, IR, and HRMS $)$ that are in good agreement with those of natural orthodiffene $A$ and orthodiffene $C$. See Supporting Information for detailed comparative ${ }^{1} \mathrm{H}$ and ${ }^{13} \mathrm{C}$ NMR of synthetic (-)-orthodiffenes A $\left(\mathbf{1}^{\prime}\right)$ and $\mathrm{C}\left(\mathbf{3}^{\prime}\right)$ and natural orthodiffenes A and C. However, the measured optical rotation for the synthetic (-)-orthodiffenes A $\left(\mathbf{1}^{\prime}\right)$ and $C\left(3^{\prime}\right)$ material does not compare well to the reported value for the natural orthodiffene $\mathrm{A}$ and orthodiffene C $\left\{(-)\right.$-orthodiffene A $\left(\mathbf{1}^{\prime}\right):[\alpha]_{\mathrm{D}}{ }^{25}-35.2$ (c 0.8 , $\left.\mathrm{CHCl}_{3}\right) ;[\alpha]_{\mathrm{D}}{ }^{25}+84.1\left(c 0.5, \mathrm{CHCl}_{3}\right)$ lit.; $^{3}(-)$-orthodiffene C $\left(3^{\prime}\right)$ : $[\alpha]_{\mathrm{D}}{ }^{25}-33.7\left(c 0.6, \mathrm{CHCl}_{3}\right) ;[\alpha]_{\mathrm{D}}{ }^{25}+139.6\left(c 1.0, \mathrm{CHCl}_{3}\right)$ lit. $\left.{ }^{3}\right\}$. We are currently working to understand this discrepancy. 